\title{
HUMAN DIGNITY UNDER THE "REBUS SIC STANTIBUS" DOCTRINE*
}

\author{
Mária Patakyová, Mária T. Patakyová, Barbora Grambličková \\ Comenius University in Bratislava, Faculty of Law
}

\begin{abstract}
This article deals with the applicability of the Rebus Sic Stantibus doctrine, which is a lawful exception to the Pacta Sunt Servanda principle. It deals with the question on whether the Rebus Sic Stantibus could be applied on the impossibilities of performance caused by subjective reasons (besides the force majeur events which are traditionally connected with the doctrine). The hypothetical situation which is discussed in the article consists in a business relation between two entrepreneurs, whereas one party exercises a personal performance for the other, and this personal performance becomes to infringe human dignity of the performer. Particularly, the article asks the question on how, if at all, it is possible for a personal performance breaching human dignity to trigger the Rebus Sic Stantibus exception. The article, after discussing the concept of human dignity as well as the Rebus Sic Stantibus doctrine; answers, that the application is possible. The Slovak legal order is chosen as the working field for this article, however, the findings are applicable more broadly, as the article also elaborates on the theoretical bases of the question at stake.
\end{abstract}

Key words: human dignity, human rights, Rebus Sic Stantibus, impossibility of performance

\section{INTRODUCTION}

The human rights are getting more and more attention during last decades. They evolved from the protection of the basic human needs to the protection of the various rights which might be questionable. One might believe that nowadays, at least in theory, the law, which is intertwined with the human rights, protects those who need it. However, this is not always the case.

Business law is a field of law designed for entrepreneurs. As a rule, the human rights should not be at stake in relations between businessmen, and the autonomy of will and the principle of contractual freedom prevail over the statutory rules in most of the cases. Nevertheless, there are situations which question the applicability of the general rules. One of such situation is when a personal performance is the object of the particular contract. What would happen if the personal performance would be against the human dignity? Naturally, many of those performances are illegal and thus cannot be an object of a valid contract. However, what if the performance started to breach human dignity only in the course of the contract? To be more specific, what if the performing party started to be abused by the ordering party in such gravity that it would be against human dignity to continue with the personal performance at stake? We deliberately choose to focus on human dignity rather than on the human rights, as the human rights are a broad concept covering many partial rights. However, as flows from the text below, human dignity should be intrinsically related with the very essence of the human beings and it should refer to the core of the human rights doctrine.

* This research has been partially presented on the conference International Conference on Business and Human Rights, organised by The Leuven Centre for Global Governance Studies (University of Leuven), the University of Seville and the BHRight Initiative. 
One possible way out is to use the doctrine Rebus Sic Stantibus. This doctrine is disputable in itself, as it is usually overridden by the general principle of Pacta Sunt Servanda, however, this does not exclude the possibility of its use. None the less, the Rebus Sic Stantibus exception is traditionally connected to the force majeur events. This article, as suggested, concentrates on the subjective impossibility of a natural person to fulfil the obligations stemming from a contract due to the infringement of his or her human dignity. Eventually, the article focuses on human dignity as a probable tool in the business relations between natural and legal persons.

Therefore, the research question of this article is: How, if at all, is it possible for a personal performance breaching human dignity to trigger the Rebus Sic Stantibus exception? In order to answer the question, the first part of this article focuses on the term human dignity and its correlation with the human rights. The second part deals with the Rebus Sic Stantibus doctrine and its application in general. To be more specific, the article chooses a concrete legal order of the Slovak Republic to show how the case would be dealt in practice.

\section{HUMAN DIGNITY}

In some national legal orders, human dignity is a well-defined concept. It is understood as a constitutional right, supreme constitutional principle or a constitutional value. ${ }^{1}$ In the very beginning, it is important to briefly define the term human dignity for its further usage. Human dignity may have various meanings, ${ }^{2}$ however, for the purposes of this article, the meaning within the context of human rights is the most predominant one. ${ }^{3}$ At its core, the term is to be understood in correlation with the equality among those whom dignity was attributed to. ${ }^{4}$ This understanding is connected to Kant and his philosophy of not using the others as the means and of the sanctity of the elementary worth of each person. ${ }^{5}$ It is also referred as the concept of autonomy. ${ }^{6}$

\section{Human Dignity in the International and the European Catalogues of Human Rights}

The interaction between the human rights and human dignity can be understood in three ways. Firstly, dignity can be understood as a foundation of the human rights. Possessing dignity permits the person to claim the human rights. ${ }^{7}$ Secondly, the society recognises dignity only because

\footnotetext{
DUPRE C. Unlocking human dignity: towards a theory for $21^{\text {st }}$ century, pp. 191-193.

For the various definitions of the term dignity, see WALDRON J. Dignity, Rights, and Responsibilities, pp. 1118-1121. Some authors state that human dignity has been connected to the human rights doctrine since the modern era of human rights. See WALDRON J. Dignity, Rights, and Responsibilities, p. 1117. On the other hand, there are researches proving that the term dignity started to be connected to persons in the USA only in the 1940 s. KABL J. Litigating Dignity: a Human Rights Framework, p. 1728. Therefore, the modern era should be understood as the era after the second world war. CHIBUNDU M. O. Can, Do, and Should Legal Entities Have Dignity? The Case of the State, p. 196. Ibid.

DUPRE C. Unlocking human dignity: towards a theory for $21^{\text {st }}$ century, p. 193.

There are opinions against this concept of human dignity, arguing that the concept of human dignity is not natural but rather moral, political and legal one. See MONSALVE V. B., ROMÁN J. A. Tensions of Human Dignity: Conceptualization and Application to International Human Rights Law, pp. 41-42. Some others state that this concept does not refer to real life, in which many people live without dignity. See DUPRE C. Unlocking human dignity: towards a theory for $21^{\text {st }}$ century, pp. 193-194. However, this is exactly the meaning we would like to stress, as it is more theoretical and as it refers to the most basic human characteristic. All people are entitled to dignity, although (unfortunately) not all people can live dignifiedly too.
} 
it recognises the rights of the person. Thirdly, dignity can simply be viewed as one of the human rights. $^{8}$

In our opinion, the first concept captures the interaction most appropriately. ${ }^{9}$ This is confirmed by the preamble of the principal document of the international protection of human rights, the Universal Declaration of Human rights, ${ }^{10}$ in which it is stated in its very first sentence, that the "[...] recognition of the inherent dignity and of the equal and inalienable rights of all members of the human family is the foundation of freedom, justice and peace in the world"11 Therefore, human dignity is inherently in every human being and the states can only recognise it, as it is necessary for the principles of freedom, justice and peace. ${ }^{12}$ The vital role of the human dignity is confirmed in the articles of the Universal Declaration, for instance Article $1^{13}$ or Article $23^{14}$. International Covenant on Civil and Political Rights follows the universal Declaration as a binding document. The Covenant's Preamble states that the human rights "[...] derive from the inherent dignity of the human person". ${ }^{15}$ Furthermore, the term may be recognised in plenty of other articles ${ }^{16}$.

The European catalogues of human rights ${ }^{17}$ are interconnected with the human dignity concept as well. Convention for the Protection of Human Rights and Fundamental Freedoms (hereinafter the ECHR) does not expressly refer to human dignity ${ }^{18}$, however, the concept is implicitly presented in various articles. ${ }^{19}$ Moreover, the explicit reference to the Universal Declaration in the preamble of the ECHR confirms the assumption that human dignity plays an essential role within the protection of human rights under the Council of Europe. Eventually, the original version of the ECHR contained only the human rights and freedoms which were broadly uncontroversial and which were built upon the natural law and the principle of human dignity. ${ }^{20}$

8 CHIBUNDU M. O. Can, Do, and Should Legal Entities Have Dignity? The Case of the State, pp. 198-202.

The third concept is partially present in the Charter of fundamental rights of the European Union. However, we believe that the mere fact that human dignity is listed as one of the fundamental rights in this document does not mean that it is not the founding idea of the human rights doctrine.

9 This is also confirmed by the other authors, although the view is not universal. See, for instance: MONSALVE V. B., ROMÁN J. A. Tensions of Human Dignity: Conceptualization and Application to International Human Rights Law, pp. 39, 54 .

10 Despite of not having legal value of a convention, the Universal Declaration has still great symbolic and practical value. See, for instance, ŠABATOVÁ, A. Ombudsman a lidská práva, p. 17.

11 Preamble of the Universal Declaration of Human Rights proclaimed by the General Assembly of the United Nations on $10^{\text {th }}$ December 1948.

12 MONSALVE V. B., ROMÁN J. A. Tensions of Human Dignity: Conceptualization and Application to International Human Rights Law, p. 45.

13 Article 1 of the Universal Declaration of Human Rights: "All human beings are born free and equal in dignity and rights. [...]"

14 Article 23 (3) of the Universal Declaration of Human Rights "Everyone who works has the right to just and favourable remuneration ensuring for himself and his family an existence worthy of human dignity, and supplemented, if necessary, by other means of social protection."

15 International Covenant on Civil and Political Rights Adopted and opened for signature, ratification and accession by General Assembly resolution 2200 A (XXI) of 16 December 1966 entry into force 23 March 1976, in accordance with Article 49.

16 See, for instance, Article 1, Article 3, Article 7, Article 10 of the International Covenant on Civil and Political Rights.

17 Under the term European catalogues of human rights, we understand, firstly, the Convention for the Protection of Human Rights and Fundamental Freedoms; secondly, the Charter of fundamental rights of the European Union.

18 Apart from Protocol 13 to the Convention for the Protection of Human Rights and Fundamental Freedoms concerning the abolition of the death penalty in all circumstances.

19 See, for instance, Article 3 Prohibition of torture; Article 4 Prohibition of slavery and forced labour; Article 14 Prohibition of discrimination.

20 RAINEY B., WICKS E., OVEY C. The European Convention on Human Rights, p. 4. 
The Charter of fundamental rights of the European Union (hereinafter "the Charter") as the human rights' catalogue of the European Union is worth mentioning in particular, since the human dignity is one of the foundations of the EU. ${ }^{21}$ Furthermore, first of the six titles of this document is named "Dignity" and it is understood as the cover name for the first generation of human rights. The very first article of the Charter is dedicated to the human dignity. ${ }^{22}$ The significance of the human dignity is furthermore stressed in relation to the rights of the elderly ${ }^{23}$, rights to fair and just working conditions $\mathbf{2}^{4}$ and may be implicitly recognised in many other provisions of the Charter.

\section{(Human) Dignity and Legal Persons}

Bearing in mind the research question of this article, the discussion on dignity of the legal persons cannot be omitted. Is a personal performance, thus a performance of a human being, different in any manner from a performance of a legal person? More broadly, could legal persons claim to possess dignity? If the answer was in the affirmative, their performance should not be differentiated from a performance of a human being.

If we understand a legal person as a contingent of the human beings possessing human dignity ${ }^{25}$, then, consequently, dignity may be transferred to the legal person itself. ${ }^{26}$ However, even though this concept may be acceptable as regards certain legal persons, such as states, it is more disputable in connection with "private" legal persons such as companies. "Private" legal persons exist because they are recognised by a state. ${ }^{27}$ This "fiction" legal personhood enables a legal person to exist separately from its owners. ${ }^{28}$ Hence, the theoretical concept based on the shift from owners' human dignity to legal person's "human" dignity bears a risk that the separate legal personhood of legal persons is eliminated. We cannot automatically entitle the legal persons of attributes of their owners, unless we diminish the existence of separate legal personhood.

Approaching the issue from another perspective, what would be the implications of ascribing dignity to legal persons? It may be claimed that certain enshrinements are already presented, such as the protection of the good name of the company or the enlargement of certain human rights, for instance right to a fair trial or right to privacy ${ }^{29}$, to the legal persons. However, we are of the opinion

21 Preamble to the Charter.

22 Article 1 of the Charter: "Human dignity is inviolable. It must be respected and protected."

23 Article 25 of the Charter.

24 Article 31 of the Charter.

25 Leaving apart the legal entities which cannot be defined in this manner, for instance contingents of the property.

26 See, mutatis mutandis, CHIBUNDU M. O. Can, Do, and Should Legal Entities Have Dignity? The Case of the State, p. 202 etc.

27 See, for instance, ŠTEVČEK M. et al. Občiansky zákonník I. \$1 - 450. Komentár, pp. 100-101.

28 Naturally, we accept that there are other theories explaining the existence of the legal persons, some of them might be even more adequate than the theory of fiction. To this end, see: PATAKYOVÁ M., CZÓKOLYOVÁ, B.: Teória společnosti v triáde rozhodnutí Daily Mail, Cartesio a VALE - spoločnost̉ ako fikcia, nexus kontraktov alebo reálna osoba?

The argument against the theory of fiction can be based also on the formulation of Section 18 para. 1 and Section 19a para 1 of the Civil Code which enable legal persons to possess full legal personhood. See: PATAKYOVÁ M. In PATAKYOVÁ, M. et al. Obchodný zákonník: komentár, p. 54.

Nevertheless, it may be claimed that, under Slovak law, legal persons do not come into existence purely by their own will, the recognition of the state is necessary.

29 Société Colas Est and others v. France App no 37971/97 (ECtHR, 16 April 2002), Delta Pekárny A.S. v. République Tchèque, App No 97/11 (EctHR 2nd October 2014). 
that the legal persons are not full holders of "human dignity", despite of the existence of certain elements which are the same as the manifestations of human dignity. The concept is well known also in the human rights field, where the legal persons can be entitled to the human rights only when it is intrinsically possible for legal persons to possess them. ${ }^{30}$

This concept is substantiated by the observation that the legal persons should possess the rights and obligations which are compatible with their nature. For instance, the right to own property is compatible with the nature of the legal persons, as it is necessary for fulfilment of the purposes which they are established to for. However, the legal persons do not have right to marry, ${ }^{31}$ as this is not compatible with their very nature. We do not need to wonder why it is so, as the very purpose of the marriage is simply not possible apart from the natural persons. ${ }^{32}$ By the same token we may claim that the legal persons have only certain enshrinements of (human) dignity. The legal persons have right not to be verbally assaulted- defamed, however, they do not have right not to be sexually assaulted, as the latter, again, is not compatible with their very nature.

\section{Human dignity in private relations}

Since this article is concerned with the questions on the human dignity in private relations, one may ask how the human rights and human dignity correlate with the private law. It is the role of a state to enforce human rights, not of a private party. ${ }^{33}$ The private law is based on the autonomy of will, thus the restrictions based on human rights protection is at odds with the former. However, the autonomy of will itself follows from the human rights doctrine, therefore the clash between them is not inevitable. What may cause an issue is the exaggerated application of the human rights in the private relations. $^{34}$

Although the human rights protection is applicable in the vertical relations between states and private persons, the state may be held liable for the infringement of the human rights via Acts of Law which do not respect the human rights; or via not protecting a private party against another private party in a judicial proceeding. Thus, the horizontal application of the human rights is connected with the positive obligations of the state. ${ }^{35}$ Applied on our research question, human dignity as the base of the human rights, cannot be ignored in the private relations, otherwise the state may be indirectly liable for the infringement of the human rights. This should result in the interpretation of the private law which is in favour for the protection of human dignity.

30 BARTOŇ M. et al. Základní práva, p. 63.

31 It is so even though certain human rights catalogues does not explicitly exclude this possibility. For instance, the Charter states in Article 9: "The right to marry and the right to found a family shall be guaranteed in accordance with the national laws governing the exercise of these rights." There is no mention that the right to marry and the right to found a family shall be guaranteed only for the natural persons.

32 The mergers are of completely different nature than marriage. At very least, in the case of a marriage, there are still two separated natural persons, which is not true as regards the mergers.

33 WEISSBRODT D.: Business and Human Rights, p. 55.

34 BARTOŇ M. et al. Základní práva, pp. 55-56.

35 BARTOŇ M. et al. Základní práva, p. 57, 58, 70, 71. 


\section{REBUS SIC STANTIBUS VERSUS PACTA SUNT SERVANDA}

\section{Meaning of the Rebus Sic Stantibus Doctrine}

Certain forms of the Pacta Sunt Servanda doctrine may be recognised in the old religions, where the gods were "guarantors" of the contract. Likewise, the Bible and the Koran teach that the obligations shall be fulfilled. ${ }^{36}$ The recognition of the principle Pacta Sunt Servanda, however, can be dated to the Roman law. It is the basic principle which overrules many others due to the fact that it brings stability to the relations between persons. ${ }^{37}$ Even though only the formally concluded contracts were seen as the valid ones back in Roman era, the Pacta Sunt Servanda principle is still valid in today's society of rather liberal conclusion of contracts.

However, what plays a vital role in the negotiations between the parties is the foreseeability of the future events, especially as regards the risk allocation. ${ }^{38}$ The economic considerations and the natural justice call the contract, once it fulfils the requirements prescribed by law, to have the effects similar to law for the participants of the contract. ${ }^{39}$ Nevertheless, what if the event in question is unforeseeable? What if the circumstances have radically changed? Should the Pacta Sunt Servanda principle prevail anyway?

The Pacta Sunt Servanda is not an unlimited principle. Rebus Sic Stantibus is likewise important for the proper functioning of the business relations as an important exception to the Pacta Sunt Servanda principle. Despite its Latin linguistic basis, it played only limited role in the Roman law. ${ }^{40}$ As recognised by Thomas Aquinas in his Summa Theologica, the Pacta Sunt Servanda principle is conditional upon the preservation of the conditions under which the contract was concluded. ${ }^{41}$ As claimed by P. J. Mazaccano, Thomas Aquinas based this idea on the works of Seneca and Cicero. ${ }^{42}$ The Rebus Sic Stantibus exception was known to canonical law since $14^{\text {th }}$ century and to the civil contract law since the beginning of the $16^{\text {th }}$ century. ${ }^{43}$ One fact ought to be borne in mind regardless of the age in which we apply the principles: there is always need for delicate balance to be preserved between them ${ }^{44}$, with the application of common sense. ${ }^{45}$

\section{Rebus sic stantibus in the Slovak legal order}

Slovak law serves as an example of a national regulation of Rebus Sic Stantibus. Before moving to the doctrine itself, it is appropriate to state that the hypothetical situation presented in the introduction

36 MARJÁK D. Klauzula Rebus Sic Stantibus, p. 342-343.

37 See, for instance, MAZACCANO P. J. Force Majeure, Impossibility, Frustration \& the Like: Excuses for Non-Performance, the Historical Origins and Development of an Autonomous Commercial Norm in the CISG, p. 6.

38 PARK W.W.: Gaps and Changed circumstances in Energy contracts: The Devil in the Detail, p. 90.

39 MARJÁK D. Klauzula Rebus Sic Stantibus, p. 342.

40 REBRO K., BLAHO P. Rímske právo, p. 346.

41 This is so regarding the contracts other than one-time contracts.

42 MAZACCANO P. J. Force Majeure, Impossibility, Frustration \& the Like: Excuses for Non-Performance, the Historical Origins and Development of an Autonomous Commercial Norm in the CISG, p. 8.

43 MARJÁK D. Klauzula Rebus Sic Stantibus, p. 344.

44 Both principles are necessary for the proper solutions of the events which occur in business relations. See: MAZACCANO P. J. Force Majeure, Impossibility, Frustration \& the Like: Excuses for Non-Performance, the Historical Origins and Development of an Autonomous Commercial Norm in the CISG, p. 6.

PARK W. W. Gaps and Changed circumstances in Energy contracts: The Devil in the Detail, p. 7.

45 PARK W. W. Gaps and Changed circumstances in Energy contracts: The Devil in the Detail, p. 102. 
of this article might be solved by various institutes of the Slovak law. For instance, Section 265 of the Slovak Commercial Code ${ }^{46}$ states that "exercise of a right that is contrary to the principles of honest business relations shall not enjoy legal protection". Therefore, if the performer refused to continue with the performance based on the fact that the further performance would infringe his or her human dignity, the ordering party could not force him or her to continue with the performance via court. Nevertheless, this article deliberately uses the Rebus Sic Statntibus doctrine, as it is the goal of the article to explore the possibilities of the doctrine for a subjective impossibility to perform.

The "impossibility of the performance", 47 as a situation legally described in Section 575 of the Slovak Civil Code ${ }^{48}$, encompasses objective as well as subjective hindrances. ${ }^{49}$ The possible situations which may be subsumed under the "impossibility of the performance" are clarified by a negative enumeration $^{50}$ in a sense that the performance is not impossible if it can be performed under more onerous conditions, with higher costs or with a delay. Consequently, if the performance does neither fall within the enumerated one, nor it is similar to them, even subjective impossibility can be seen as "impossibility" in the sense of the referred provision. ${ }^{51}$

The duality of the contracts' regulation in the Slovak Legal order implies that it is necessary to look into the regulation of the Slovak Commercial Code too. As the parties in our hypothetical situation are in a business relationship, the Commercial Code would apply to them. ${ }^{52}$ It is important to note that the Commercial Code is lex specialis to the Civil Code. It flows from the principle of subsidiarity that the rules of the Civil Code will apply unless the Commercial Code set different rules. The impossibility of the performance is only partially regulated in the Commercial Code and the basic provisions are encompassed in the Civil Code which were discussed above.

The Commercial Code adds to the specification of the "impossibility" a situation when the obligation can be fulfilled with aid of another person. ${ }^{53}$ However, in the case of personal performance, this possibility is implicitly excluded. ${ }^{54}$

As to the further conditions imposed to the debtor, he or she is obliged to notify to the creditor, without superfluous delay, the circumstance which makes the performance impossible, otherwise the debtor will be liable for the damage caused by the undue notice. ${ }^{55}$ The Commercial Code adds that the burden of proof as to the performance being impossible lies on the debtor who is also li-

46 Act no. 513/1991 Coll. Commercial Code.

47 Traditionally, impossibility of the performance is divided into the legal impossibility and the factual impossibility. See: ŤAPÁK, J. In VOJČÍK, P. et al. Občiansky zákonník, stručný komentár, p. 766. However, part of the legal doctrine subsumes the legal impossibility under Section 39 of the Civil Code with the consequence of absolute invalidity of the legal act. See: SEDLAČKO, F. In ŠTEVČEK, M. et al. Občiansky zákonník II. §451-880. Komentár, p. 2028.

Act no. 40/1964 Coll. Civil Code.

49 FEKETE I., FEKETEOVÁ M. Občiansky zákonník. Prehladný komentár, p. 793.

50 Section 575 (2) of the Slovak Civil Code.

51 Although, it has to be admitted that opposite opinions can be found as well, claiming that the subjective impossibility cannot be accepted. See: KRISTOVÁ, K. In LAZAR, J. et al. Občianske právo hmotné 2, p. 98.

52 This fact is based on the Section 261 of the Slovak Commercial Code.

53 Section 352 (1) of the Slovak Commercial Code.

54 It is necessary to stress that there is also a special provision in relation to agreement on conclusion of a future contract, where Section 292 (5) of the Slovak Commercial Code states: "The obligation to conclude the future contract or supplement the missing content of the contract also expires if the circumstances to which the parties clearly referred when this obligation was established have changed to such a degree that it may not be reasonably required of the obliged party to conclude the contract. However, expiry shall occur only if the obliged party notified the entitled party of this change of circumstances without undue delay." However, this is considered to be out of the reach of the presented article.

55 Section 577 (1) of the Slovak Civil Code. 
able for damage caused by the termination ${ }^{56}$ of the contract, unless there is a circumstance which excludes the liability according to the general provisions on compensation of damage. " $A$ circumstance excluding liability shall be deemed an obstacle that occurred independently of the intent of the obliged party and that prevents them from fulfilling their obligation, if it may not be reasonably assumed that the obliged party could have averted or overcome this obstacle or its consequences, or that they could have foreseen this obstacle at the time when the obligation was established." debtor cannot be "[...] already in default in fulfilment of their obligation, or by an obstacle that arose from their economic situation." ${ }^{59}$ The circumstance excluding liability must be objective ${ }^{60}$, unpredictable, inevitable. ${ }^{61}$ In any case, it is essential to bear in mind that it is only a default rule and thus may be subject to amendment by the parties. ${ }^{62}$

Hence, the Slovak legal system distinguishes between the termination of the contract and the liability for damages due to this termination. For the former, it is necessary to fulfil the conditions of Rebus Sic Stantibus provisions, however, in the practical terms, it is also necessary to fulfil the provisions for the exclusion of liability, otherwise the performing party would be obliged to compensate the damages which may diminish the meaning of the Rebus Sic Stantibus exception.

Therefore, applied to our hypothetical situation, this hypothetical situation is not listed in the negative enumeration. Likewise, the performance cannot be done by another person. It is also inevitable for the impossibility of performance to be of permanent character and to be impossible and not only more onerous. Assuming that the performer notified the ordering party of the impossibility, the requirements of the Slovak legal order are met. However, to exclude the liability for damages caused by this termination of the contract, the performer would need to prove six conditions ${ }^{63}$. First, the impossibility of performance occurred independently of his intent. ${ }^{64}$ Second, it prevents him from fulfilling his obligation. ${ }^{65}$ This condition is inherently present in the Rebus Sic Stantibus doctrine itself. The same is true about the third condition, namely averting and overcoming the obstacle causing the impossibility of the performance. ${ }^{66}$ However, a particularly difficulty arises regarding the fourth condition, as the obstacle could have not been foreseen at the time when the obligation was established. ${ }^{67}$ Therefore, it is not enough to prove that the infringement of human dignity was not present at the moment of the inception of the contract, but it is also necessary to prove that this infringement was not foreseeable. Fifth, the performing party cannot be already in default in fulfilment of his obligation. ${ }^{68}$ Sixth, the impossibility of performance cannot arise

56 Moreover, it shall be noted that the termination of the contract, as foreseen by the Slovak legal system, does not exclude the possibility of the voluntary re-negotiation of the contract by the parties.

57 Sections 373 - 386 of the Slovak Commercial Code.

58 Section 374 (1) of the Slovak Commercial Code.

59 Section 374 (2) of the Slovak Commercial Code.

60 The objectivity of a circumstance excluding liability is the same as the objectivity of a circumstance triggering Rebus Sic Stantibus exception. Thus, the infringement of human dignity may be seen as an objective circumstance, as it is objectively impossible for the performer to continue with his obligations.

61 ĎURICA M. In PATAKYOVÁ, M. et al. Obchodný zákonník: komentár, p. 1260.

62 Ibid., pages 1215. 1261. See also Section 263 (1) of the Slovak Commercial Code.

63 The conditions need to be met cumulatively. See ĎURICA M. In PATAKYOVÁ, M. et al. Obchodný zákonník: komentár, p. 1261.

64 Section 374 (1) of the Slovak Commercial Code.

65 Section 374 (1) of the Slovak Commercial Code.

66 Section 374 (1) of the Slovak Commercial Code.

67 Section 374 (1) of the Slovak Commercial Code.

68 Section 374 (2) of the Slovak Commercial Code. 
from his economic situation. ${ }^{69}$ This should not be the case when the infringement of the human dignity is at stake.

\section{CONCLUSION}

Nowadays, the human rights are penetrating into more and more fields of law. Commercial law is, with some exceptions, immune from the human rights considerations. The articles on business and human rights are usually connected with the obligations of supranational companies to observe the human rights. These obligations are based on the international law. However, what is often out of the scope is the situation when the infringement of the human rights occurs directly in the business relationship between two entrepreneurs.

We believe that this situation should not stay unregulated. However, rather than adopting new rules, the solution should be seen in a reasonable interpretation of the already existing rules. Thus, returning to our research question, we claim that a personal performance breaching human dignity may trigger the Rebus Sic Stantibus exception. Yet, as stated in the last part of the article, the conditions for its launching are rigid and uneasy to fulfil. This is even more true when it comes to the exclusion of the liability for damages. The conditions for exclusion should be met, otherwise the performer will be punished for the impossibility of the performance. The strictness of the law may be seen in a positive way too, as it prevents the misuse of the Rebus Sic Stantibus doctrine.

To conclude, the mere fact that the subjective impossibility to perform a personal performance in a business relation may be based on an infringement of human dignity is interesting, as it overrides the principle of objectivity which is present in commercial law in general. However, this exception is acceptable for the proper functioning of the business relations as well as for the fulfilling of the functions of law per se.

\section{Bibliography:}

BARTOŇ M. et al. Základní práva. 1 ${ }^{\text {st }}$ Edition. Praha: Leges, 2016. 608 p. ISBN 978-80-7502-128-1.

CHIBUNDU M. O. Can, Do, and Should Legal Entities Have Dignity?: The Case of the State. In: Maryland Law Review 2015, no. 75, pp. 194-209.

DUPRE C. Unlocking human dignity: towards a theory for $21^{\text {st }}$ century. In: European Human Rights Law Review, 2009, no. 2, pp. 190-205.

FEKETE I., FEKETEOVÁ M. Občiansky zákonník. Prehladný komentár. $1^{\text {st }}$ Edition. Bratislava: EPOS, 2012.1314 p. ISBN 978-80-8057-972-2.

KABL J. Litigating Dignity: a Human Rights Framework. In: Albany Law Review, 2010-2011, no. 74, pp. 1725-1738.

LAZAR, J. at al. Občianske právo hmotné 2. $1^{\text {st }}$ edition. Bratislava : IURA EDITION, 2010. 549 p. ISBN 978-80-8078346-4.

MARJÁK D. Klauzula Rebus Sic Stantibus. In LENHARTOVÁ, K. et al. (eds.) Mílniky práva v stredoeurópskom priestore $1^{\text {st }}$ Part. $1^{\text {st }}$ Edition. Bratislava: Univerzita Komenského v Bratislave, Právnická fakulta, 2012, pp 342-351. ISBN 978-80-7160-317-7.

69 Section 374 (2) of the Slovak Commercial Code. 
MAZACCANO P. J. Force Majeure, Impossibility, Frustration \& the Like: Excuses for Non-Performance, the Historical Origins and Development of an Autonomous Commercial Norm in the CISG, [online, 10 ${ }^{\text {th }}$ November 2017]. Available at http://papers.ssrn.com/sol3/papers.cfm?abstract_id=1982895.

MONSALVE V. B., ROMÁN J. A. Tensions of Human Dignity: Conceptualization and Application to International Human Rights Law. In: International Law Journal on Human Rights, 2009, no. 11, pp. 39-60.

PARK W.W.: Gaps and Changed circumstances in Energy contracts: The Devil in the Detail. In: Journal of World Energy Law and Business, 2015, no. 8, pp. 89-102.

PATAKYOVÁ, M. et al. Obchodný zákonník: komentár. 5 th Edition. Prague : C. H. Beck, 2016. 1691 p. ISBN $978-$ 80-7400-314-1.

PATAKYOVÁ M., CZÓKOLYOVÁ B. Teória spoločnosti v triáde rozhodnutí Daily Mail, Cartesio a VALE - spoločnost' ako fikcia, nexus kontraktov alebo reálna osoba? In: Právny obzor, 2015, no. 98, pp. 3-21.

RAINEY B., WICKS E., OVEY C. The European Convention on Human Rights. $7^{\text {th }}$ Edition. Oxford: Oxford University Press, 2017. 692 p. ISBN 972-0-19-876774-9.

REBRO K., BLAHO P. Rímske právo. 3 ${ }^{\text {rd }}$ Edition. Bratislava: IURA EDITION, 2003. 496 p. ISBN 808904753x.

ŠABATOVÁ, A.: Ombudsman a lidská práva. $1^{\text {st }}$ Edition. Brno : DOPLNĚK, 2008. 200 p. ISBN 978-80-7239-229-2.

ŠTEVČEK, M. et al. Občiansky zákonník II. \$ 451-880. Komentár. Praha: C. H. Beck, 2015. 3208 p. ISBN 978-807400-597-8.

VOJČÍK, P. et al. Občiansky zákonník, stručný komentár. 3 ${ }^{\text {rd }}$ Edition. Bratislava: IURA EDITION, 2010. 1282 p. ISBN 978-80-8078-368-6.

WALDRON J. Dignity, Rights, and Responsibilities. In: Arizona State Law Journal, 2011, no. 43, pp. 1107-1135.

WEISSBRODT D. Business and Human Rights. In: University of Cincinnati Law Review, 2005-2006, no. 74, pp. 55-74.

\section{Contact information:}

prof. JUDr. Mária Patakyová, CSc.

maria.patakyova@flaw.uniba.sk

Comenius University in Bratislava, Faculty of Law

JUDr. Barbora Grambličková, LL.M. (neé Czókolyová)

barbora.czokolyova@uniba.sk

Comenius University in Bratislava, Faculty of Law

JUDr. Mária T. Patakyová, PhD.

maria.patakyova2@flaw.uniba.sk

Comenius University in Bratislava, Faculty of Law

Šafárikovo nám. č. 6

P. O. BOX 313

81000 Bratislava

Slovak Republic 